\title{
Ecotourism Promotes Conservation Activity at Tourism Destinations: Limestone Forest Langkawi
}

\author{
Abu Ali 1, Siti Salwa Isa 1, Siti Suriawati Isa ${ }^{2}$, Mohd Husba Isa ${ }^{2}$ \\ ${ }^{1}$ Department of Industrial Design, Faculty of Art \& Design, Universiti Teknologi MARA, 40450 Shah Alam Selangor, Malaysia \\ ${ }^{2}$ Department of Recreation and Ecotourism, Faculty of Forestry, Universiti Putra Malaysia, 43400 Serdang Selangor, Malaysia \\ abuali@uitm.edu.my, sitisalwa@uitm.edu.my, ssuria4@upm.edu.my, husbaisa91@gmail.com \\ Tel: 013-4017304
}

\begin{abstract}
This study aims to investigate the role of ecotourism activities and programs in promoting the conservation and protection of the limestone forest at tourism destinations in Langkawi. University students from Malaysia and Australia collaborated in this case study to gather data on the applicability of using ecotourism as a tool for conservation activities in Langkawi. Three field trips were undertaken to the Langkawi limestone forests, where researchers employed onsite observation and face to face interviews with 30 stakeholders from multiple backgrounds. The result indicated that through hands-on experience, ecotourism promotes the conservation and protection of the limestone forest.
\end{abstract}

Keywords: ecotourism, conservation, limestone forest, Langkawi

eISSN: 2398-4287 @ 2021.. The Authors. Published for AMER ABRA cE-Bs by e-International Publishing House, Ltd., U.K. This is an open access article under the CC BYNC-ND license (http://creativecommons.org/licenses/by-nc-nd/4.0). Peer-review under responsibility of AMER (Association of Malaysian Environment-Behaviour Researchers), ABRA (Association of Behavioural Researchers on Asians) and cE-Bs (Centre for Environment-Behaviour Studies), Faculty of Architecture, Planning \& Surveying, Universiti Teknologi MARA, Malaysia.

DOI: https://doi.org/10.21834/ebpj.v6iSl6.3047

\subsection{Introduction To Ecotourism}

Ecotourism has become the most important niche tourism market or alternative form of the tourism industry for more than three decades. Romeril (1985) is the first person to coin the ecotourism term. It is an important economic activity in natural areas (Drumm et al. 2004), including localities with limited resources. One of the most quoted ecotourism definitions in the literature is Ceballos-Lascurain (1987:14; 1991). He stated that ecotourism is ".....travelling to relatively undisturbed or uncontaminated natural areas with the specific objective of studying, admiring, and enjoying the scenery and its wild plants and animals, as well as any existing cultural manifestation (both past and present) found in these areas". This definition demonstrates that ecotourism refers to activities that educate tourists about the local natural environment to provide a complete experience (Diamantis 1999). Ecotourism, rather than alternative synonymous terms, is used here in line with the Malaysian tourism industry and research community terminology.

According to the concept of ecotourism, the lesser the development at any one ecotourism destination, the higher the value of the destination to ecotourism tourists (Ceballos-Lascurain 1987). Accordingly, ecotourism practices should adhere to strict rules and regulations to benefit the environment and future generations. While ecotourism activists and operators may not always apply ecotourism principles and practices, instead of undertaking activities that may harm the environment and natural resources (Valentine 1993), ecotourists might be expected to be more responsible towards the environment than other types of tourists. The focus of this study is to investigate the benefits of ecotourism in promoting conservation activities at a tourism destination.

eISSN: 2398-4287@ 2021. The Authors. Published for AMER ABRA cE-Bs by e-International Publishing House, Ltd., UK. This is an open access article under the CC BYNCND license (http://creativecommons. org/licenses/by-nc-nd/4.0/). Peer-review under responsibility of AMER (Association of Malaysian Environment-Behaviour Researchers), ABRA (Association of Behavioural Researchers on Asians/Africans/Arabians) and cE-Bs (Centre for Environment-Behaviour Studies), Faculty of Architecture, Planning \& Surveying, Universiti Teknologi MARA, Malaysia.

DOI: 


\subsection{Ecotourism Promotes Conservation Activity At Tourism Destinations In Langkawi}

The Malaysian government is very much committed to the concept of sustainable development in the tourism industry. At the 50th Pacific Asia Tourism Association (PATA) Conference in Kuala Lumpur, Malaysia endorsed five resolutions, including adopting sustainable tourism and enhancing ecotourism. Evidence of the government's intent is reflected in establishing parks and protected areas to support sustainable tourism development in the country. The Ministry of Tourism and Culture (MoTAC) has also taken steps to introduce tourism as a core subject in local universities and support the teaching of the theme in schools. The National Ecotourism Plan, prepared by the then Ministry of Culture, Arts and Tourism in 1997, consists of 25 guidelines. These cover, among other aspects, categorizing sites and activities, carrying capacity and limits of acceptable change (LAC), marine parks and islands, national parks and reserves, mangroves, use of local accommodation, accreditation of ecotourism products and visitors' roles and responsibilities (MoTAC, 2015). In 2017, MOTAC developed The National Ecotourism Plan 2016-2025, with a significant focus on promoting sustainable development and conserving and protecting ecotourism sites in Malaysia, recognizing the significant role of ecotourism in conservation.

Ecotourism activities can promote pro-environmental behaviour towards natural areas (Ajuhari, Isa and Aziz, 2016), such as; enhancing conservation and protection of culture, forest, river and wildlife. Nowadays, natural areas need more conservation and protection due to the rapid development of natural areas happening worldwide. Many scholars agree that the ecotourism sector of the tourism industry is a mechanism that could be used to create awareness of, conserve and protect natural areas; Ibrahim and Isa (2018); Leung, Spenceley, Hvenegaard and Buckley (2018) and MoTAC (2015) stated that tourists take part in ecotourism activity because it promotes environmentally-friendly and responsible tourism. However, as increasing interest in participating in ecotourism activities and programs may negatively impact a tourism destination (WWF 2007), management bodies must introduce stricter rules and regulations to maintain a sustainable tourism destination and environment. In addition, there has been concern about environmental damage due to the current levels of consumerism (Gatersleben, Murtagh and Abrahamse 2012). Since Langkawi is well known for its tourism activities, sustainable tourism development should be emphasized on the island. Tourism operators and stakeholders in Langkawi must strictly follow ecotourism rules and regulations to protect the island's environment. The Malaysian federal government agency Langkawi Development Authority (LADA) should play an active role in conserving and protecting Langkawi's culture, environment and natural settings.

Most ecotourism activities and programs are held around natural areas (Valentine,1993). Some of these natural areas are located inside protected areas, such as reserved forests and United Nations Educational Scientific and Cultural Organisation (UNESCO) Global Geoparks. Protected areas are a key component of global conservation strategy (Leung et al., 2018). In Malaysia, the Kilim Karst Geoforest Park, Langkawi (also known as Kilim Geopark), is one of the best-known limestone forests and is a UNESCO Global Geoparks site. Kilim Geopark covers an area of 100 square kilometres and attracts significant numbers of tourists. Unfortunately, many other limestone forests in Malaysia have not received public attention, and their extinction has gone unnoticed (WWF, 2016). Compared to the rainforest or mangrove forest conservation and protection topics, limestone forests are the type of forest least likely to be mentioned anywhere in the literature (WWF, 2016). Thus, it is time to use ecotourism activities and programs to enhance the conservation and protection of limestone forests. The nature of ecotourism practices and principles make this a suitable tool to promote conservation and protection of the tourism destination (Boley and Green 2016).

\subsection{Research Problem And Objective}

Previous researchers agree that by applying ecotourism practices, destinations may have a longer life span and minimize environmental damage. Langkawi Island is a popular tourist spot in Malaysia, which lost many forested areas during rapid tourism development; deforestation for tourism development in Langkawi has become the biggest threat to the local natural environment in recent years, including at limestone forest areas (WWF, 2016). While most of the limestone forests belong to private owners on the island, they are often mined for marble. Hence, there is a need for the local community and tourism operators in Langkawi to adopt responsible tourism practices through ecotourism before more harm occurs on the island. Since most of the population on the island are heavily dependent on tourism as their main source of income, the ecotourism concept presents a workable solution to help conserve and protect the island's environment and nature whilst maintaining key income.

This study aims to investigate the role of ecotourism activities and programs in promoting the conservation and protection of the limestone forest at tourism destinations in Langkawi. This comprises two research questions:

$\mathrm{RQ1}$ : Do ecotourism activities and programs help to promote limestone forest conversation and protection in Langkawi?

$\mathrm{RQ2}$ : What types of ecotourism activities provide the highest impact on limestone forest conservation and protection in Langkawi?

\subsection{Case Study Approach}

Since the research area is relatively understudied and relevant data are poorly documented in the literature, a case study approach is used to answer the research questions (Yin, 2003). The strength of the case study method is its ability to examine, in-depth, a "case" within its "real-life" context (Yin, 2003, p 111-112; Isa et al., 2011). This study is among the first on limestone forests in Penarak, Langkawi and will contribute rich data set about this topic through the case study approach. Importantly, it is not the intention of this study to generalize the study findings. 


\subsection{Study Area}

70 students from Universiti Putra Malaysia (UPM), Queensland University of Technology (QUT) and Universiti Teknologi MARA (UiTM) took part in this case study to gather data on the applicability of using ecotourism as a tool for conservation activities in Penarak and UNESCO Geopark Kilim, Langkawi. The first study area is located at Batu Ayam and Batu Orkid, situated next to each other in Penarak, Langkawi, at about five minutes' boat ride from the Penarak jetty and approximately 5 kilometres from Kuah town. At present, there is no access road to Batu Ayam and Batu Orkid. The site is approximately 13 hectares, with the highest peak at 400 meters above sea level. Limestone forest comprises the primary forest and has several water sources, mainly fresh water from a natural pond and saltwater from the two beaches.

Local geology consists of limestone with some marble and granite and sediments (Lee, 2014). The whole area belongs to Penarak Nature Centre (PNC) Sdn. Bhd. and is not open to the public (refer figure 1). However, PNC plans to open a research and conservation centre at the limestone forest in the future. The second study area is the UNESCO Geopark located at Kilim, Langkawi, a popular ecotourism destination in Malaysia. As the first UNESCO Geopark in Southeast Asia, this area attracts significant tourists from all over the world each year. The PNC area and UNESCO Geopark are close to each other, only separated by the sea.

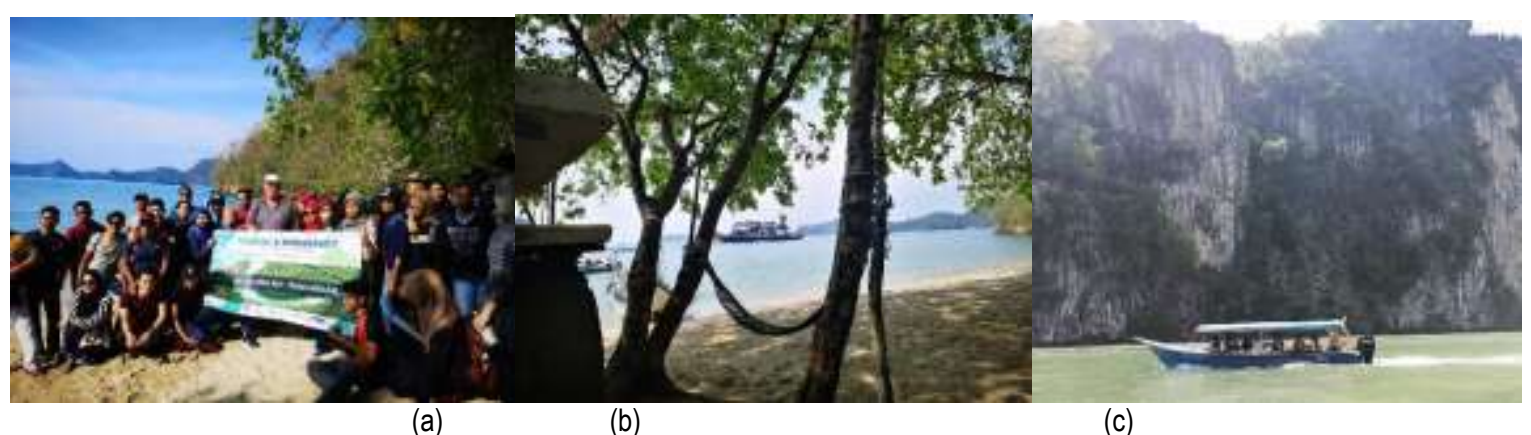

Fig. 1. $1^{\text {st }}$ Case study area at private island Penarak (a \& b) and $2^{\text {nd }}$ Case study UNESCO Geopark Kilim (c), Langkawi

\subsection{In-Person Interviews}

The General Manager at PNC Sdn Bhd first supplied expert testimony to the team, followed by interviews with 2 experts in the Malaysian forest and biology fields. Then, the team conducted several activities related to limestone forest awareness and interviewed 15 visitors who participated in the events alongside 12 interviews with local residents (see table 1). Interview data were analyzed using thematic analysis as appropriate for qualitative data (Boyatzis 1998; Sutton and Austin 2015) and presented by identified themes to address the two research questions. Secondary data are also used to support the primary data.

Table 1. Basic information of the participants

\begin{tabular}{|l|l|l|l|}
\hline Participants & 3 experts (E) & 15 visitors (V) & 12 local residents (LC) \\
\hline Age & $45-56 y r s$ & $26-57 y r s$ & $28-62 y r s$ \\
\hline Additional Info & General Manager PNC_E1 & Gov. Servant_V1, V2 & Tourist guide_LC1, LC2 \\
& Forestry experts_E2 & Lecturers_V3, V4 & General workers_LC3, LC4 \\
& Biology experts_E3 & Accountant_V5 & Cleaners_LC5, LC6 \\
& & Researchers_V6, V7 & Boatmen_LC7, LC8 \\
& & Business Owner_V8, & Fishermen_LC9 \\
& & Photographer_V9, V10 & Renjer_LC10, LC11 \\
& Studnets_V11,V12,V13,V14,V15 & Students_LC12 \\
\hline
\end{tabular}

What types of ecotourism activities provide the highest impact on limestone forest conservation and protection in Langkawi?

\subsection{Findings and Discussion}

RQ1: Do ecotourism activities and programs help to promote limestone forests in Langkawi?

Since 2018, the research team has organized eight activities and programs on the limestone forest in Langkawi to create awareness of their conservation and protection among the participants. This provision took place at Penarak and Kilim and involved activities including; experts and nature guide talks, fieldwork and watching documentaries. Most participants were primary, secondary, and university students and people from the local community. Based on the interviews, most particpiants agreed that they are more aware of the existence and importance of limestone forests, particularly in Langkawi, since participating in the ecotourism activities and programs. Furthermore, they also want the limestone forest area to be protected.

\subsection{Interview with the experts}

An interview with the General Manager (E1) revealed that PNC Sdn. Bhd. bought the limestone forest area in Penarak, Langkawi, in 2014 solely for awareness and conservation purposes. He witnessed the island developed rapidly, resulting in significant major damage to the natural areas. As a foreigner, he had decided to migrate to Langkawi because of its beautiful environment, particularly its beaches and forest. Unfortunately, the current focus on development for mass tourism attractions on the island may cause more significant harm to 
Langkawi's natural environment in the future. For example, at Kilim Geopark, a popular ecotourism site in Langkawi, where a jetty collapsed and 12 visitors were injured (Bernama 2018). Rather than focusing on duty-free shops, island hopping and other mass tourism activities at Langkawi, the PNC. Sdn. Bhd., General Manager, aimed to have more awareness and conservation campaigns on the environment, mainly the limestone forest in Langkawi and Malaysia. Through his time at Penarak, he has learned that the limestone forest in Langkawi has its own uniqueness compared to other parts in Malaysia because it is closer to Thailand. Still, not many people are aware of this fact. Promoting ecotourism activities and programs is not sufficient to fully follow the practices and principles of ecotourism. Campaigning to save the limestone forest in Langkawi has been limited. The forestry expert (E2) interviewed also had similar views. He commented that "... Langkawi is developing too fast, but I don't think the locals entirely understand the environmental damages from the rapid development of the island...."

Nonetheless, he is not against tourism development and activities; he wants sustainable development or responsible tourism practices such as; ecotourism to be imposed on the island. The expert (E3) from the biological field commented that; "...The awareness and conservation activities and programs organized for the students are great. Coming from a pure science background, we didn't realize that ecotourism can help to promote conservation, and for this case, it is the limestone forest conservation and plus it is fun...."

A report by W.W.F. Malaysia (2016) stated that the limestone forest in Langkawi is facing extinction due to tourism development on the island. In addition, the construction of new buildings and development of areas, such as commercial accommodation, duty-free shops and food and beverages outlets, has been a normal scenario in Langkawi for the last few years. Local and international companies are competing to invest billions of ringgit in Langkawi, primarily for tourism-related businesses. While massive development creates job opportunities for the locals, longer-term the environmental impact may contribute significant damage to livelihoods on the island.

\subsection{Interview with the local residents}

From informal conversations conducted with twelve local residents in Langkawi, they had no clue why P.N.C. Sdn. Bhd. is interested in the limestone hill and forest, if not for mining for marble. To them, nothing is interesting about the area and what P.N.C. Sdn. Bhd is doing now is useless, wasting money and time if the area cannot be developed for mining or other mass tourism activities. In addition, staff of P.N.C. (LC3, LC4) were interviewed, and they were aware of illegal trespassing and poaching of wildlife on their land and reported it to the Department of Wildlife and National Park (DWNP) Malaysia, Kedah branch. However, their staffing levels make this problem difficult to prevent. Based on our phone interview with DWP staff at the Kedah branch stated that they fully support awareness and conservation programs relating to wildlife and national parks. Due to that, they have a few units looking after education, environmental recreation, training and wildlife.

\subsection{Findings on Ecotourism program}

$\mathrm{RQ2}$ : What types of ecotourism activities provide the highest impact on limestone forest conservation programs in Langkawi?

The research team organized eight ecotourism activities and programs for limestone forest awareness and conservation for different tourists from Malaysia and Australia. At the same time, LADA sponsored free tour packages to UNESCO Geopark in Kilim for the participants. After participating in all activities and programs, ten participants were interviewed randomly in Langkawi to get their opinions. The participants choose the top three highest impact activities, and programs are as follows;

\section{i) Guided Tour at Limestone Forest Areas with Experienced Tour Guide}

15 respondents interviewed agreed that a guided tour with an experienced tour guide helped them better understand limestone forests, particularly in Langkawi. Before the tour, they watched a video and lecture about the limestone forest in Langkawi. Still, they felt that the guided tour with an experienced guide at the limestone forest provided the highest impact. They felt closer to the limestone forest after the guided tour because they could have interactive sessions with the tour guide and firsthand experience of the areas. All respondents were more interested in learning about limestone forests after participating and want to join efforts to protect them in the future. As one of the respondents commented, "....Now whenever I come across limestone forest articles or passed by limestone forest formations, I tend to read them with interest or try to find out more about the formation compared to before this...". All respondents agree that the uniqueness of limestone forest in Langkawi should be highlighted as an ecotourism product that needs to be protected through conservation activities and programs. They also suggested that the study area should be open to the public, especially for awareness, education, and research purposes, to learn more about limestone forest formation, with stricter rules and regulations imposed on all visitors.

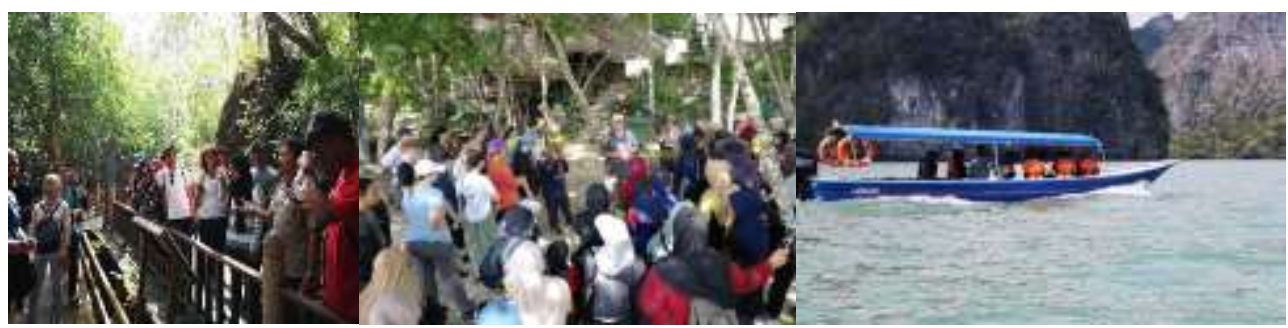

Fig. 2. Guided Tour at Limestone Forest Areas with Experienced Tour Guide 
ii) Limestone Awareness and Conservation Program

Awareness and conservation activities and programs involving many agencies, students, and staff were the second-highest impact conservation program chosen by the respondents.

The respondents worked closely together in groups during the program, enabling them to engage with their cultures, overcome cultural barriers, and learn about the limestone forest. Through their combined efforts, awareness of conservation and protection of limestone forests has been increased for Malaysian participants and Australian participants.

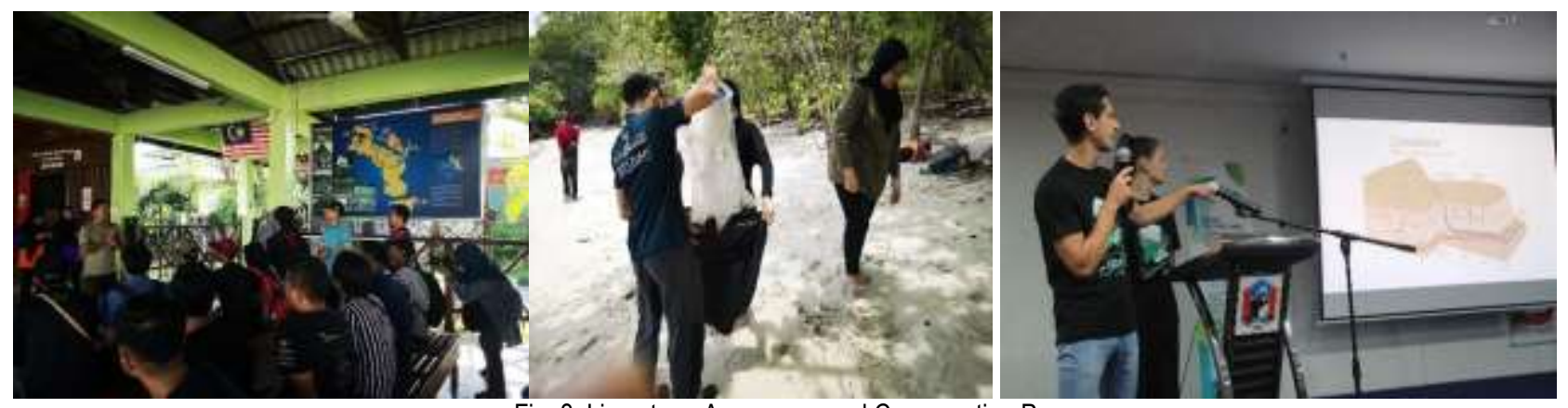

Fig. 3. Limestone Awareness and Conservation Program

\section{iii) Knowledge Sharing among Participants}

The majority of the respondents felt that knowledge sharing among participants was useful, particularly if it was done using creative and innovative methods such as; sketches, building mockup models, role-play and video presentations. They also responded positively to the organizer facilitating competitions during the activities and programs, as they developed their relationships with each other during competitions. The competition jury commented that "All of the participants were so creative and competitive with each other. We can see they put a lot of effort in their work and want to win the competition.....". Participants became more aware of other people's perspectives of limestone forests through such knowledge sharing. Before the participants engaged in sketches, building mockup models, role-play and video presentations, they had to conduct research on limestone forests. As a result, they became more aware of limestone forests and their importance for the environment.

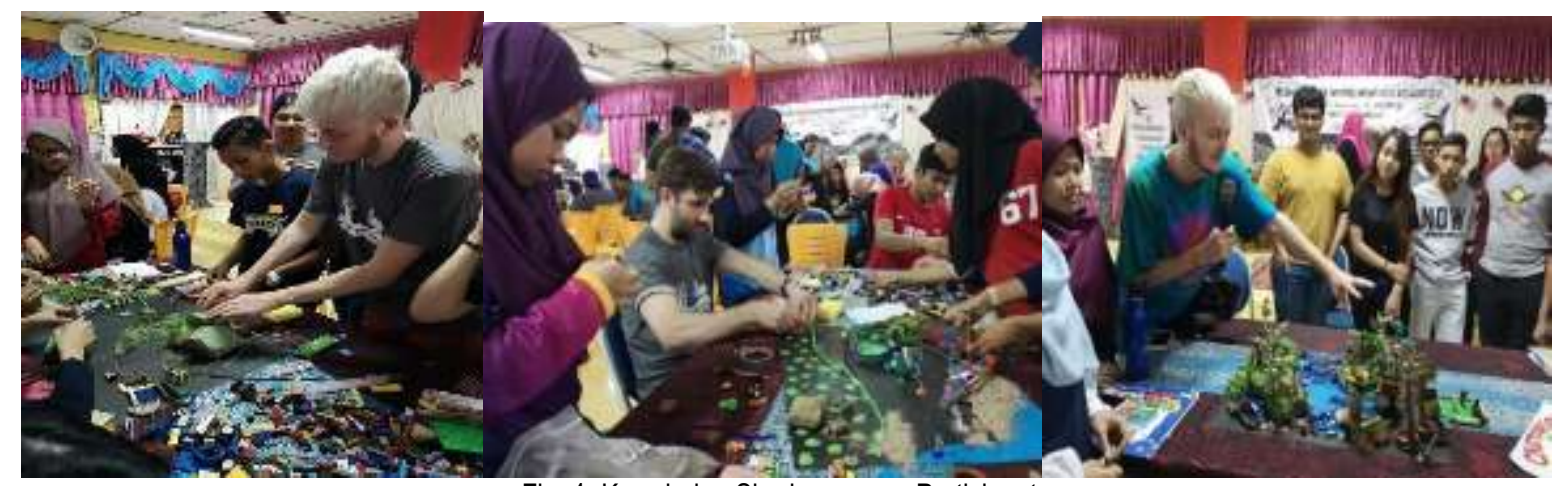

Fig. 4. Knowledge Sharing among Participants

\subsection{Conclusion}

This study found that ecotourism activities and programs help to promote conservation at tourism destinations. Participants have higher awareness and knowledge after taking part in ecotourism activities and programs. They also realized the importance of conservation and supported the conservation and protection program to save limestone forests in Langkawi and expand to other parts of Malaysia. At the same time, participants from Australia want the program to be organized in Australia. Hence, this result has answered the first research question of this study. As for the second research question, this study found that the participants enjoyed multidisciplinary activities and programs rather than single discipline activities and programs. Multidisciplinary studies should be promoted to get a better result, bringing more significant benefits and understanding to everyone. Importantly, each participant gained significant experience from ecotourism activities for the limestone forest conservation program, covering art, culture, science and social science disciplines. This is the evidence shown from the respondents' top three highest impact of limestone forest conservation and protection activities. Future researchers and tourism stakeholders should consider this when conducting studies or organising ecotourism activities and programs.

\section{Acknowledgements}

This study is partially funded by Penarak Nature Centre (PNC) for a project on exploring the potential of hydrological study in a limestone forest, North Peninsular Malaysia. The authors are grateful to the Managing Director of Penarak Nature Centre, Mr Sergey Grechkin for 
his financial support and assistant during the study was undertaken. The authors wish to thank Faculty of Forestry, University of Putra and Queensland University of Technology, Australia for their contribution, support and kind collaboration in this project. Also, the authors are grateful to Langkawi Development Authority (LADA), the Department of Kedah Forestry Department and everyone who help this project directly or indirectly.

\section{References}

Action on Bio Science (2016, May 2016). Retrieved from http://www.actionbioscience.org/environment/lowman.html

Ajuhari, Z., Isa, S.S., Aziz, A. (2016). Promoting Pro-environmental Behaviour in Ecotourism Destination. In: Regional Conference on Science, Technology and Social Sciences (RCSTSS 2016), Mohamad Amli Abdullah et al. (Eds.). Springer Science+Business Media Singapore, pp. 1023-1039.

Bernama (2018, October 2018). 12 orang cedera selepas jeti Pulau Tikus runtuh. p. 1, 29 Oktober 2018, Retrieved from http://www.bernama.com/bm/news.php?id=1659078

Bhatt, H. (2014, July 2014). Langkawi Risks Losing Geopark Status afer Unesco 'Yellow Card'. Malaysia Edition, Jul. 15, $2014 . \quad$ Retrieved from http://www.themalaysianinsider.com/malaysia/article/rm38-million-set-aside-to-strengthen-langkawis-geopark-status\#sthash.j2WbCzsY.dpuf

Boley, B. B., and Green, G. T. (2016). Ecotourism and natural resource conservation: the 'potential'for a sustainable symbiotic relationship, Journal of Ecotourism, 15(1), $36-50$.

Ceballos-Lascurain, H. (1987:14; 1991). The Future of Ecotourism. Mexico Journal, 13-14.

Ceballos-Lascurain (1991). Tourism, Ecotourism and Protected Areas. Parks, 2(3), 31-35.

Christ, C. (2007, October 2015). Green Travel Comes of Age. National Geographic. Retrieved from http://www.nationalgeographic.com/adventure/travel/eco-travel/ecosuccess.html

Clements, R., Sodhi, N. S., Schilthuizen, M., \& Peter, K. L. Ng. (2006). Limestone Karsts of Southeast Asia: Imperiled Arks of Biodiversity. Bioscience, 56:733-742.

Dawum, G. (2013). Edu-pelancongan UPM (UPM Edu-tourism). Utusan Malaysia. Retrieved from http://ww1.utusan.com.my/utusan/Kampus/20130128/ka_03/Edupelancongan-UPM

Gatersleben, B., Murtagh, N., and Abrahamse, W. (2012). Values, Identity, and Pro-environmental Behaviour. Contemporary Social Science: Journal of the Academy of Social Sciences, 9(4), 1-20.

Global Geoparks Network (2012). Retrieved from http://www.unesco.org/new/fileadmin/MULTIMEDIA/HQ/SC/pdf/SC_Geopark_Langkawi_IDcard-Malaysia2012.pdf

Ibrahim, N.A. and Isa, S.S. (2018). Pilot Study on Visitors' Segmentation at Penang National Park Based on Place Attachment, Malaysia Forester, 8(2), $154-161$.

Lam, J.M.S., Ariffin, A.A.M., \& Ahmad, A,H. (2011). Edutourism: Exploring the Push-Pull Factors in Selecting a University. International Journal of Business and Society, $12: 1$.

Lee, C.P., 2014: Geological Field Guide to Langkawi. Geological Society of Malaysia: https:/gsmpubl.wordpress.com/2014/09/02/geological-field-guide-to-langkawi/

Leung, Yu-Fai, Spenceley, Anna, Hvenegaard, Glen, and Buckley, Ralf (eds.) (2018). Tourism and Visitor Management in Protected Areas: Guidelines for Sustainability.

Li, T.C. (2015). Stop Quarrying Hills for Limestone, Dig for It Instead. The Star, July 13. htpp://www.mykarst.org/. (Accessed on 02 May 2016).

Mack, C. (2016). Responsible Travel. Retrieved from http://www.responsibletravel.com/holidays/responsible-tourism/travel-guide/ecotourism

MacKinnon, K., Hatta, G., Halim, H., \& Mangalik, A. (1996). The Ecology of Kalimantan. The Ecology of Indonesia Series, Volume III. Periplus Editions, Hong Kong.

Ministry of Tourism and Culture Malaysia (2015). Ecotourism Guideline. Retrieved from http://www.motac.gov.my/en/programme/courses/eco-host-malaysia

Ministry of Tourism and Culture Malaysia (2017). National Ecotourism Plan 2016-2025. Retrieved from http://www.motac.gov.my/en/download/category/86-pelan-ekopelancongan-kebangsaan-2016-2025

Mohammed Abubakar, A., Shneikat B.H.T., \& Oday, A. (2014). Motivational Factors for Educational Tourism: A Case Study in Northern Cyprus. Tourism Management Perspectives, $11,58-62$.

Ngo, T.L., \& Holcher, D. (2014). The Fate of Five Rare Tree Species after Logging in a Tropical Limestone Forest (Xuan Son National Park, Northern Vietnam). Tropical Conservation Science, $7(2): 326-341$.

Norizan Md. Nor (2000) Nature Attractions in the Region. Paper presented at Seaceum 7 Seminar, 26-27 September 2000.

Naturally Langkawi (2015). About Langkawi: Geopark, Myths and Lagends, Soul of Langkawi. Retrieved from http://naturallylangkawi.my/

Romeril, M. (1985). Tourism and the Environment towards a Symbolic Relationship. International Journal of Environmental Studies, 25: 215- 218.

The International Ecotourism Society (2013, January 2016). How Can Tourism Create Win-Win Solution for Conservation and Communities? Retrieved from https://www.ecotourism.org/news/how-can-tourism-create-win-win-solution-conservation-and-communities 
Ali, A.., et.al. / International Virtual Colloquium on Multi-disciplinary Research Impact (1st Series), Shah Alam, Malaysia, 15 Oct 2021, E-BPJ, 6(SI6), Oct 2021 (pp. 107-113)

The Star (2010). Ministry to Work with Media to Promote Green, Clean Campaign. p. 1. Retrieved from https://envdevmalaysia.wordpress.com/2010/10/22/ministry-to-workwith-media-to-promote-clean-green-campaign/

Valentine, P.S. (1993). Ecotourism and Nature Conservation: A Definition with Some Recent Developments in Micronesia. Tourism Management 14(2): 107-115.

Weaver, D.B. (2005). Comprehensive and Minimalist Dimension of Ecotourism. Annals of Tourism Research, 32(2), 439-455.

World Wildlife Fund (W.W.F.) (2007). W.W.F. on Coastal Development: Tourism. Retrieved from W.W.F. on Coastal development problems: Tourism

World Wildlife Fund (W.W.F.) Malaysia (2016). Limestone Forest and Caves. Retrieved from http://www.wwf.org.my/about_wwf/what_we_do/forests_main/the_malaysian_rainforest/types_of_forests/limestone_forests_and_caves/

Yin (2003). Case Study Research: Design and Methods (Third Edition). SAGE Publications, Inc.: California. 